\title{
Authors in this Issue
}

Sune Ákerman, docent at the University of Uppsala, started with a study on financial history. He has also treated political history and migrational and demographic history in general with a strong emphasis on methodological problems. He is now working on an evaluation of family reconstitution technique.

ReIno Kero, docent in American History at the University of Turku, has studied emigration history since 1963, has written two books on emigration history: Migration from Finland to North America in the Years between the United States Civil War and the First World War (dissertation for Ph.D. in 1974), and Suuren Lannen Suomalaiset (The Finns of the Great West in 1976). He is now studying the migration in the early 1930s of Finnish immigrants from Canada and the USA to the area now known as Soviet Karelia.

Helgi Skúli Kuartansson studied at the University of Iceland, Reykjavik (B.A. 1972), University College, London and again in Reykjavik (cand. mag. 1976 with a thesis on Icelandic emigration, its volume and composition), where he now teaches modern economic history besides working on a history of the cooperative movement in Iceland.

Bo Kronborg, Ph.D. and Thomas Nrlsson, Ph.D. are working as researchers in a Uppsala University project on "The family in the Swedish demographic and social transformation since 1800." Their thesis, Stadsflyttare (Urban Migrants), presented as a teamwork, treated problems concerning migration and social mobility in connection with industrialisation and urbanisation. Presently they are studying family demographic and social changes in urban areas.

IngRId Semmingsen, Professor of History at the University of Oslo, has studied problems concerning emigration for many years. Her most famous work is Veien mot Vest I, II (The Way West I, II.). At present she is working on aspects dealing with social history and American history.

KJELL SöDERBERG is working on a doctor's dissertation at the University of Umeå, on population mobility and its selective mechanisms connected with the Swedish emigration during the 19th century. 
Andres A. Svalestuen has been employed at the Norwegian National Archives (Riksarkivet) since 1969. He received his cand. philol. degree from the University of Oslo in 1968, with history as the main subject. He has published Tinns emigrasjonshistorie 1837-1907 (The Emigration History of Tinn Parish 1837-1907), and a comparative study of Nordic emigration in a report to the Nordic conference on history in 1971 (Oslo 1972 and Copenhagen 1971).

Arne Vangdrup, Ph.D., has been working on a study of migration at the Institute of Economic History, University of Copenhagen since 1974. His contribution to the project "Nordic Emigration" is part of a more comprehensive thesis on the demographic and migratory conditions in Torslev Parish, 18701901. 